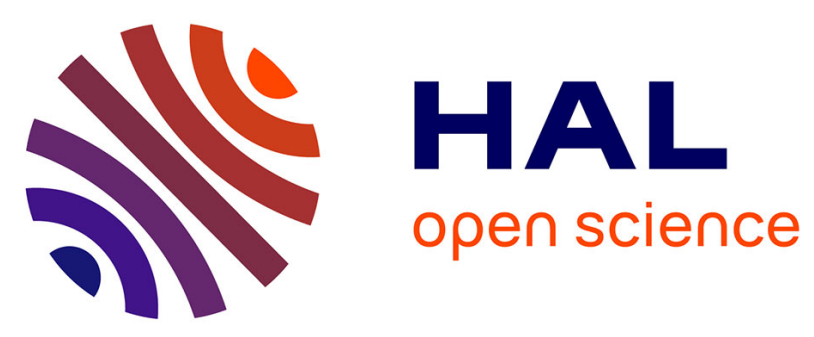

\title{
From static alteration to mylonitization: a nano- to micrometric study of chloritization in granitoids with implications for equilibrium and fluid percolation length scales
}

Laura Airaghi, Benoit Dubacq, Anne Verlaguet, Franck Bourdelle, Nicolas Bellahsen, Alexandre Gloter

\section{To cite this version:}

Laura Airaghi, Benoit Dubacq, Anne Verlaguet, Franck Bourdelle, Nicolas Bellahsen, et al.. From static alteration to mylonitization: a nano- to micrometric study of chloritization in granitoids with implications for equilibrium and fluid percolation length scales. vEGU21, 2021, Online, France. 10.5194/egusphere-egu21-1053 . hal-03554568

\author{
HAL Id: hal-03554568 \\ https://hal.science/hal-03554568
}

Submitted on 3 Feb 2022

HAL is a multi-disciplinary open access archive for the deposit and dissemination of scientific research documents, whether they are published or not. The documents may come from teaching and research institutions in France or abroad, or from public or private research centers.
L'archive ouverte pluridisciplinaire HAL, est destinée au dépôt et à la diffusion de documents scientifiques de niveau recherche, publiés ou non, émanant des établissements d'enseignement et de recherche français ou étrangers, des laboratoires publics ou privés. 
EGU21-1053

https://doi.org/10.5194/egusphere-egu21-1053

EGU General Assembly 2021

(c) Author(s) 2022. This work is distributed under

the Creative Commons Attribution 4.0 License.

\title{
From static alteration to mylonitization: a nano- to micrometric study of chloritization in granitoids with implications for equilibrium and fluid percolation length scales
}

\author{
Laura Airaghi ${ }^{1}$, Benoit Dubacq ${ }^{2}$, Anne Verlaguet ${ }^{2}$, Franck Bourdelle ${ }^{3}$, Nicolas Bellahsen ${ }^{2}$, and \\ Alexandre Gloter ${ }^{4}$ \\ ${ }^{1}$ Université d'Orléans, CNRS, BRGM, ISTO, Orléans, France (laura.airaghi@univ-orleans.fr) \\ ${ }^{2}$ Sorbonne Université, CNRS-INSU, Institut des Sciences de la Terre de Paris, ISTeP, Paris, France \\ ${ }^{3}$ Université Lille, IMT Lile Douai, Université Artois, Yncrea Hauts-de-France, LGCgE, Laboratoire de Génie Civil et géo- \\ Environnement, Lille, France \\ ${ }^{4}$ Laboratoire de Physique du Solide, CNRS, Université Paris-Saclay, Orsay, France
}

Strain accommodation in upper crustal rocks is often accompanied by fluid-mediated crystallization of phyllosilicates, which influence rock strength and shear zone formation. The composition of these phyllosilicates is commonly used for pressure-temperature-time constraints of deformation events, although it is often highly heterogeneous. This study investigates the reactions producing a phyllosilicate, chlorite, in and below greenschist-facies conditions and the variations in chlorite composition, along a strain gradient in the Bielsa granitoid (Axial Zone, Pyrenees). Compositional maps of chlorite (including iron speciation) are compared to nanostructures observed by transmission electron microscopy in increasingly-strained samples and related to mechanisms of fluid percolation and scales of compositional homogenisation. In the Bielsa granitoid, altered at the late Variscan, Alpine-age shear zones are found with high strain gradients. The undeformed granitoid exhibits local equilibria, pseudomorphic replacement and high compositional heterogeneities in chlorite. This is attributed to: (i) variable element supply and reaction mechanisms observed at nanoscale and (ii) little interconnected intra- and inter-grain nanoporosity causing isolation of fluid evolving in local reservoirs. In samples with discrete and $\mathrm{mm}$-sized fractures, channelized fluid triggered the precipitation of homogeneous Alpine chlorite in fractures, preserving late-Variscan chlorite within the matrix. In low-grade mylonites, where brittle-ductile deformation is observed, micro-, nano-cracks and defects allows the fluid percolating into the matrix at the scale of hundreds of $\mu \mathrm{m}$. This results in a more pervasive replacement of late-Variscan chlorite by Alpine chlorite. Local equilibria and high compositional heterogeneities in phyllosilicates as chlorite are therefore preserved according (i) matrix-fracture porosity contrasts at nanoscale and (ii) the location and interconnection of nanoporosity between crystallites of phyllosilicates that control reaction mechanisms and element mobility. In low grade mylonites, mineral and compositional replacement remains incomplete despite the high strain. 